\title{
Cyclic lipopeptide profile of the plant-beneficial endophytic bacterium Bacillus subtilis HC8
}

\author{
Natalia Malfanova $\cdot$ Laurent Franzil $\cdot$ \\ Ben Lugtenberg • Vladimir Chebotar · \\ Marc Ongena
}

Received: 13 February 2012/Revised: 2 May 2012 / Accepted: 10 May 2012/Published online: 31 May 2012

(C) The Author(s) 2012. This article is published with open access at Springerlink.com

\begin{abstract}
In a previous study (Malfanova et al. in Microbial Biotech 4:523-532, 2011), we described the isolation and partial characterization of the biocontrol endophytic bacterium $B$. subtilis HC8. Using thin-layer chromatography, we have detected several bioactive antifungal compounds in the methanolic extract from the acidprecipitated supernatant of $\mathrm{HC} 8$. In the present study, we have further analyzed this methanolic extract using liquid chromatography-mass spectrometry. Based on the comparison of retention times and molecular masses with those of known antifungal compounds, we identified three families of lipopeptide antibiotics. These include four iturins A having fatty acyl chain lengths of $\mathrm{C} 14$ to $\mathrm{C} 17$, eight fengycins $\mathrm{A}$ (from $\mathrm{C} 14$ to $\mathrm{C} 18$ and from $\mathrm{C} 15$ to $\mathrm{C} 17$ containing a double bond in the acyl chain), four fengycins $\mathrm{B}$ (C15 to C18), and five surfactins (C12 to C16). Evaluation of the antifungal activity of the isolated lipopeptides showed that fengycins are the most active ones. To our knowledge, this is the first report of an endophytic Bacillus subtilis producing all three major families of lipopeptide antibiotics containing a very heterogeneous mixture of
\end{abstract}

Communicated by Wolfgang Buckel.

N. Malfanova $(\bowtie) \cdot$ B. Lugtenberg

Sylvius Laboratory, Institute of Biology, Leiden University,

Sylviusweg 72, 2333 BE Leiden, The Netherlands

e-mail: N.Malfanova@biology.leidenuniv.nl

N. Malfanova $\cdot$ V. Chebotar

All-Russian Research Institute for Agricultural Microbiology

(ARRIAM), Saint-Petersburg-Pushkin, Russia

L. Franzil $\cdot$ M. Ongena

Walloon Centre for Industrial Biology, Bio-Industry Unit,

Gembloux Agro-Bio Tech, University of Liege,

5030 Gembloux, Belgium homologues. The questions remain open which of these lipopeptides (1) are being produced during interaction with the plant and (2) are contributing to the biocontrol activity of $\mathrm{HC} 8$.

Keywords Endophytic - Bacillus - Cyclic lipopeptides . LC-MS

\section{Introduction}

Endophytes are plant-associated microbes that are able to colonize plants internally. Due to the nature of their endophytic lifestyle, they establish a long-lasting stable relationship with a plant. In this symbiotic association, the plant provides nutrients and shelter for the microbes and, in turn, the endophyte can help the plant by protecting it against phytopathogens or by promoting its growth. One of the mechanisms of such a protection includes production of bioactive secondary metabolites which either can be directly involved in antibiosis (Thomashow and Weller 1995; Haas and Défago 2005; Lugtenberg and Kamilova 2009) and/or in triggering induced systemic resistance (ISR) (Tran et al. 2007; Ongena et al. 2007). Bacillus spp. are known to produce a wide range of secondary metabolites including cyclic lipopeptides (c-LPs), some of the most powerful ones with regard to their antifungal and biosurfactant activity (Ongena and Jacques 2008; Jacques 2011).

Secondary metabolites produced by Bacillus spp. consist mainly of three families of non-ribosomally synthesized c-LPs. These are the iturins, the fengycins, and the surfactins. These c-LPs contain a peptide ring with seven (iturins and surfactins) or 10 (fengycins) amino acids linked to a $\beta$-hydroxy (fengycins and surfactins) or $\beta$-amino (iturins) fatty acid. Each lipopeptide family is further 
subdivided into groups based on its amino acid composition. For example, the fengycin family comprises fengycin $A$ and fengycin $B$, which differ in a single amino acid in the sixth position (D-alanine and D-valine, respectively). Within each group, there are homologues differing in the length, branching, and saturation of their acyl chain (Ongena and Jacques 2008). Members of the iturin family range from $\mathrm{C} 14$ to $\mathrm{C} 17$, fengycins from $\mathrm{C} 14$ to $\mathrm{C} 19$, and surfactins from $\mathrm{C} 12$ to $\mathrm{C} 17$. Both iturins and fengycins are mainly known for their anti-fungal properties, while surfactins are mostly anti-viral and anti-bacterial. When different families are co-produced, their interaction can become synergistic and enhances each of their respective activities (Maget-Dana et al. 1992; Ongena et al. 2007; Romero et al. 2007).

In our previous work (Malfanova et al. 2011), we have described the isolation and partial characterization of the plant-beneficial endophytic bacterium $B$. subtilis HC8. This strain shows strong in vitro antifungal activity against various fungal phytopathogens. When applied to seeds, B. subtilis HC8 is able to significantly decrease symptoms of tomato foot and root rot which is caused by the phytopathogen Forl. The crude methanolic extract from the acidprecipitated supernatant fluid of this strain contains several bioactive compounds which behave similar to some known lipopeptide antibiotics on a TLC plate. Taking together, all these data suggested that $B$. subtilis $\mathrm{HC} 8$ produces several lipopeptide antibiotics which might be important for its antifungal and biocontrol activities. Therefore, the aims of this study were (1) to identify the putative lipopeptides produced by the beneficial endophytic strain Bacillus subtilis $\mathrm{HC} 8$, (2) to characterize the antifungal activity of the isolated c-LPs families against Forl in an in vitro bioassay, (3) to test whether there is synergistic activity between the families of c-LPs toward Forl in vitro, and (4) whether active c-LPs affect hyphal morphology.

\section{Materials and methods}

Extraction of antifungal compounds

The extraction of antifungal compounds was performed as described in our previous study (Malfanova et al. 2011). Briefly, B. subtilis HC8 was grown in Brain Heart Infusion broth (BHI, Difco Laboratories, MI, USA) for $60 \mathrm{~h}$ at $28{ }^{\circ} \mathrm{C}$. Subsequently, cells were removed by centrifugation at 13,000 r.p.m. for $10 \mathrm{~min}$. The supernatant fluid was acidified to $\mathrm{pH} 2.0$ with concentrated $\mathrm{HCl}$. The resulting precipitate was extracted twice with methanol, the combined extracts were concentrated by vacuum evaporation, and the resulting material was subsequently dissolved in $1 / 50$ th of the initial culture volume of methanol.
Identification of c-LPs using LC-MS analysis

Putative c-LPs were identified as described by ArguellesArias et al. (2009) using LC-MS analysis. Briefly, the crude methanolic extract was analyzed by reverse-phase high-pressure liquid chromatography (Waters Alliance $2695 /$ diode array detector) coupled to a quadrupole mass analyzer on an X-Terra MS $150 \times 2.1 \mathrm{~mm}, 3.5 \mu \mathrm{m} \mathrm{C} 8$ column (Waters, Milford, MA, USA). Lipopeptides were eluted using a two component solvent system of which solvent $\mathrm{A}$ is water and solvent $\mathrm{B}$ is acetonitrile, both acidified with $0.1 \%$ formic acid. We used four different elution programs including one general program to elute all lipopeptides and three family-specific programs to get a better separation and quantification of the different lipopeptides within each family (Table 1). All elution programs used a flow rate of $0.5 \mathrm{ml} / \mathrm{min}$ and detection occurred using the positive ion mode.

Table 1 Elution programs used in HPLC. Solvent A is water, acidified with $0.1 \%$ formic acid, and solvent B is acetonitrile, acidified with $0.1 \%$ formic acid. The curve indicates the rate at which the solvent is changed to the new compositions, curve 1 is exponential and curve 6 is linear

\begin{tabular}{|c|c|c|c|}
\hline Time & $\mathrm{A} \%$ & B\% & Curve \\
\hline \multicolumn{4}{|c|}{ a General elution program } \\
\hline 0 & 57 & 43 & 1 \\
\hline 1.5 & 57 & 43 & 1 \\
\hline 17 & 37 & 63 & 6 \\
\hline 17.5 & 20 & 80 & 6 \\
\hline 26 & 0 & 100 & 6 \\
\hline 27 & 57 & 43 & 6 \\
\hline 35 & 57 & 43 & 6 \\
\hline \multicolumn{4}{|c|}{ b Iturin-specific elution program } \\
\hline 0 & 62 & 38 & 1 \\
\hline 20 & 55 & 45 & 6 \\
\hline 25 & 50 & 50 & 6 \\
\hline 27 & 0 & 100 & 6 \\
\hline 32 & 0 & 100 & 6 \\
\hline 33 & 62 & 38 & 6 \\
\hline 40 & 62 & 38 & 6 \\
\hline \multicolumn{4}{|c|}{ c Fengycin-specific elution program } \\
\hline 0 & 60 & 40 & 1 \\
\hline 20 & 35 & 65 & 6 \\
\hline 21 & 0 & 100 & 6 \\
\hline 26 & 0 & 100 & 6 \\
\hline 27 & 60 & 40 & 6 \\
\hline 35 & 60 & 40 & 6 \\
\hline \multicolumn{4}{|c|}{ d Surfactin-specific elution program } \\
\hline 0 & 22 & 78 & 1 \\
\hline 20 & 22 & 78 & 1 \\
\hline
\end{tabular}


Identification of lipopeptides was based on the comparison of retention times and molecular masses with those of known c-LPs (Ongena et al. 2005; Ongena and Jacques 2008). As a control, the $95 \%$ pure authentic standards for each family were used. The fengycin A and B lipopeptides with identical molecular mass and retention time were distinguished as described by Sun et al. (2006) based on the formation of specific product ions upon mild conditions of fragmentation of molecular ions. Product ions with massto-charge value $(\mathrm{m} / \mathrm{z}) 966$ and 1080 correspond to fengycin A while those at m/z 994 and 1108 correspond to fengycin B. Amount of each lipopeptide family present in the sample was calculated based on calibration curves of purified iturins, fengycins, and surfactins available in the laboratory.

Evaluation of antifungal activity of the isolated c-LPs

Antifungal activity of the isolated c-LPs was evaluated in the 96-well microtiter plate assay against Forl. To do this, the suspension of fungal spores, adjusted to a density of $5 \times 10^{5}$ spores $/ \mathrm{ml}$, was combined either with single compounds dissolved in methanol ranging from 3 to $100 \mu \mathrm{g} / \mathrm{ml}$ or with their combination according to the co-production profile (iturins $47 \%$, fengycins $36 \%$, and surfactins $17 \%$ ) in a final volume of $150 \mu \mathrm{l}$ of half strength Potato Dextrose Broth (PDB, Difco Laboratories, MI, USA). In the positive control, c-LPs were replaced with the corresponding volume of methanol. In the negative control, no spores and no c-LPs were added. Inoculated plates were incubated for $25 \mathrm{~h}$ at $30{ }^{\circ} \mathrm{C}$ and subsequently the fungal growth was determined by measuring the optical density (OD) at $620 \mathrm{~nm}$ with a microplate reader. To see the impact of c-LPs on fungal morphology, fungal hyphae treated with $100 \mu \mathrm{g} / \mathrm{ml}$ of c-LPs were observed with an Axioskop2-type microscope using a $40 \times$ objective (Carl Zeiss Jena $\mathrm{GmbH}$, Germany). All experiments were performed at least twice.

\section{Results and discussion}

LC-MS was performed on a crude methanolic extract of the acid-precipitated supernatant fluid of B. subtilis HC8. To elute all putative c-LPs, we used a general elution program (Table 1a). This program uses a gradient of increasing amounts of acetonitrile (a polar solvent) and thus the first eluents include the less polar iturins followed by the increasingly polar fengycins and surfactins (Fig. 1). Iturins and fengycins are less separated compared to surfactins due to the similar polarity of the biggest iturins and the smallest fengycins. Based on calibration curves for standard c-LPs, iturins represent the most abundant family of the lipopeptides $(65 \mu \mathrm{g} / \mathrm{ml}$ culture supernatant, followed by fengycins $(50 \mu \mathrm{g} / \mathrm{ml})$ and surfactins $(23 \mu \mathrm{g} / \mathrm{ml})$.

Before the elution of surfactins (20-22 min), several peaks appeared that correspond to unknown compounds that could be related to surfactin lipopeptides based on their chromatographic behavior and fragmentation pattern. Preliminary analysis of their product ions (results not shown) indicates that these compounds contain unusual amino $\operatorname{acid}(s)$ in their peptide moiety. The presence of unknown surfactin-like compounds can be either specific for
Fig. 1 LC-MS analysis of the crude methanolic extract from the acid-precipitated supernatant fluid of $B$. subtilis HC8. Analysis was performed as described by Arguelles-Arias et al. (2009). a iturins A; b fengycins; c surfactins; d unknown compounds

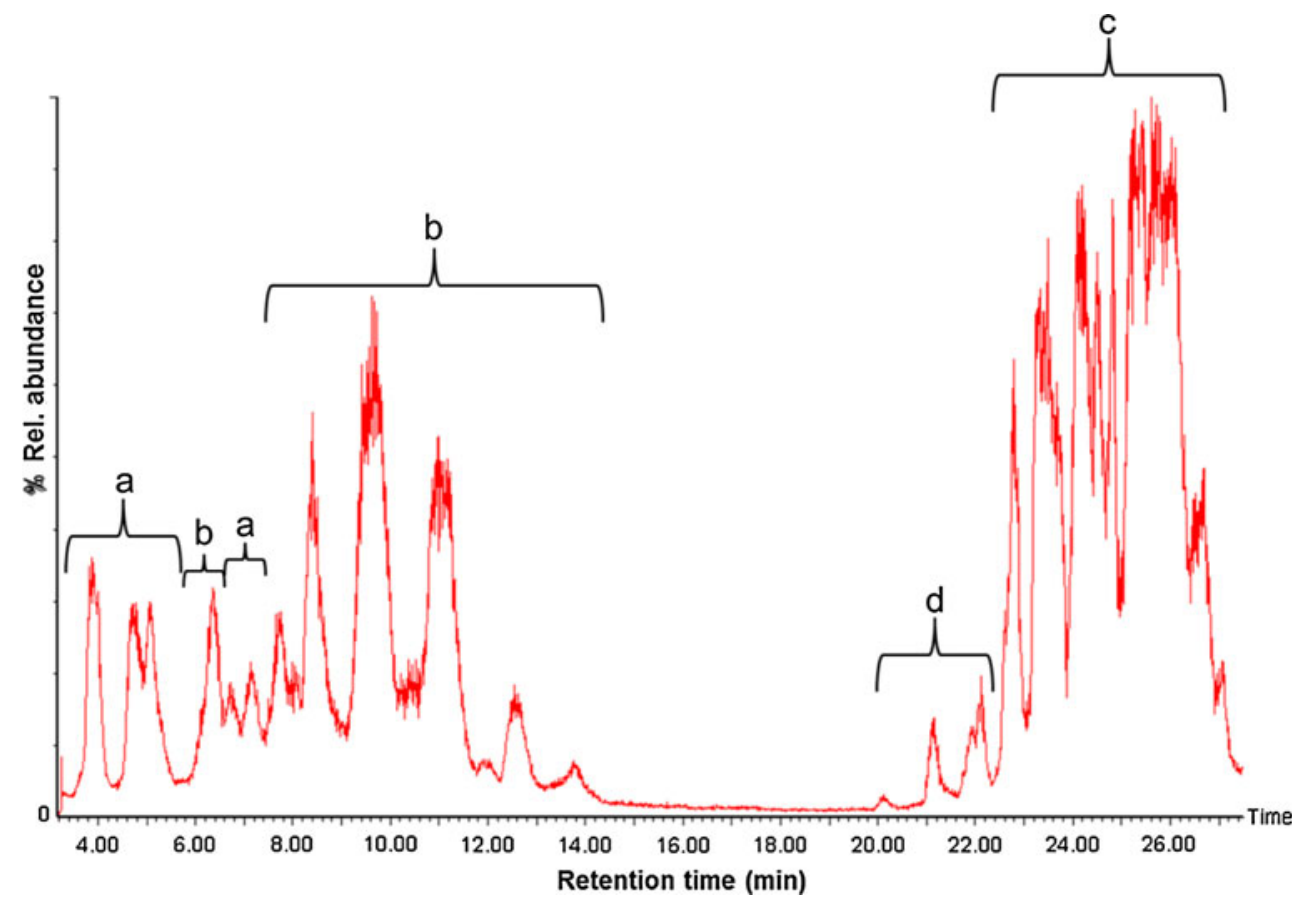


B. subtilis $\mathrm{HC} 8$ or due to relative abundance of certain amino acids in the medium. A possible influence of the composition of the medium was shown in several studies (Peypoux et al. 1994; Grangemard et al. 1997). For example, addition of L-alanine to the growth medium resulted in incorporation of this amino acid in the fourth position of the peptide ring of surfactins instead of the usual amino acid L-valine (Peypoux et al. 1994). This can be explained by the non-specificity of the adenylation domain of some non-ribosomal peptide synthetases involved in surfactin biosynthesis (Jacques 2011).
Additional culturing in various growth media, purification, and analysis would be required to elucidate the exact composition and structure of these minor unknown surfactin-like compounds detected in the present study.

To obtain a better separation and quantification of the different lipopeptides of the same family, we ran three family-specific programs (Tables 1b-d). The iturin-specific program revealed the presence of all four members of iturin A, having fatty acyl chain lengths from $\mathrm{C} 14$ to $\mathrm{C} 17$ (Table 1; Fig. 2a). The most abundant homologue is $\mathrm{C} 15$, followed by $\mathrm{C} 14, \mathrm{C} 16$, and $\mathrm{C} 17$. The fatty acid chain
Fig. 2 Family-specific LC-MS analysis of the methanolic extract of B.subtilis HC8. Each lipopeptide family was characterized using specific elution gradients as described elsewhere (Toure et al. 2004). a Iturin-specific analysis. The homologues of iturin A contain C14-C17 acyl chains.

b Fengycin-specific analysis. A, fengycin A; B, fengycin B; 15, 18 include $\mathrm{C} 15$ fengycin A homologue with an unsaturated fatty acyl chain and the saturated $\mathrm{C} 18$ homologue. Fengycins A C16 and $\mathrm{C} 17$ homologues with a double bond elute together with $18 \mathrm{~B}$. c Surfactin-specific analysis. The homologues of surfactin contain C12-C16 acyl chains
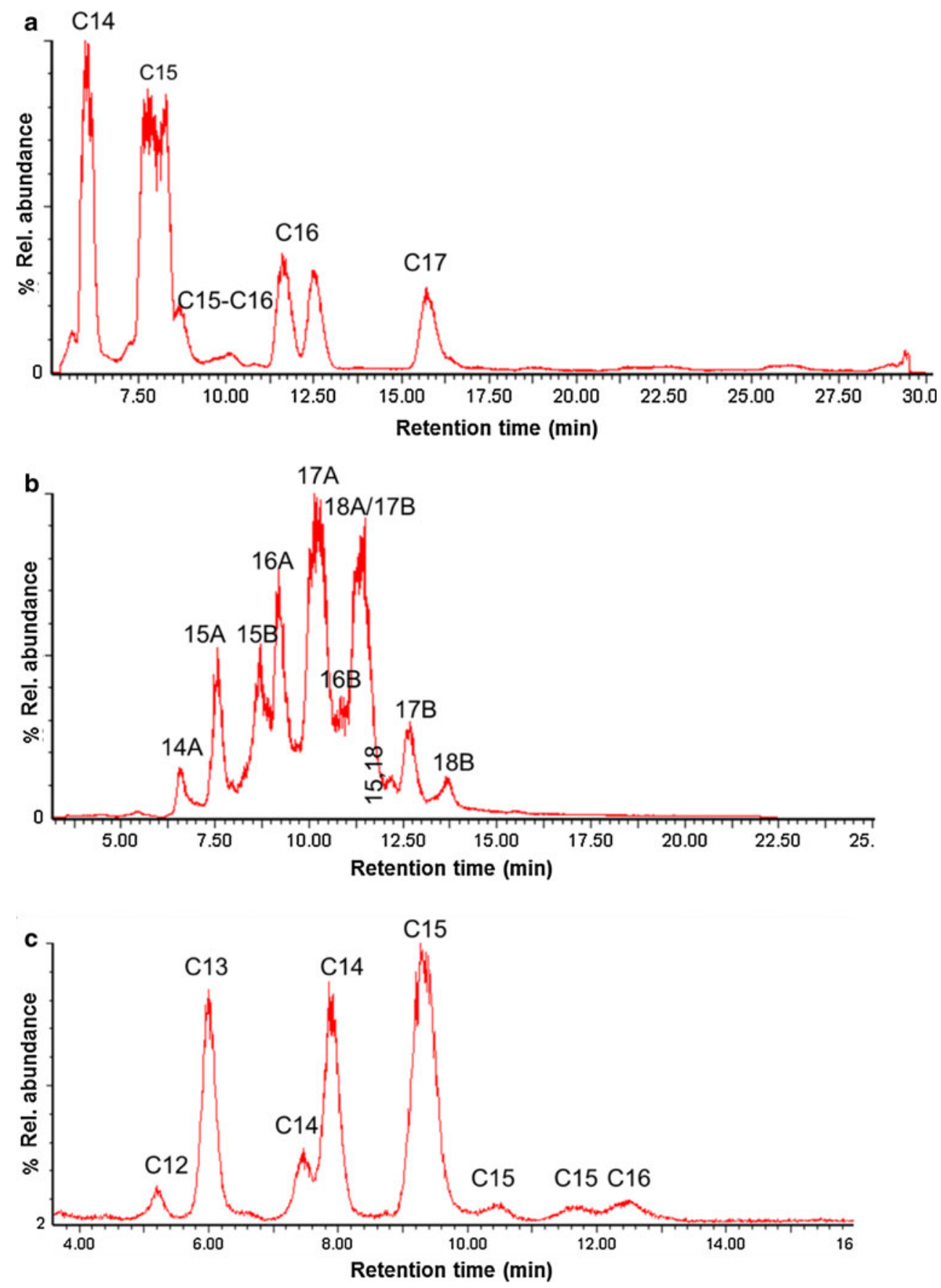
length of iturins is known to be important for their antifungal activity which increases with increasing number of carbon atoms (Bonmatin et al. 2003; Shai et al. 2006; Tabbene et al. 2011). For example, it has been shown that the C16 homologue of bacillomycin D-like compound, which is a member of the iturin family, displayed the strongest fungicidal activity in vitro against Candida albicans whereas $\mathrm{C} 14$ and $\mathrm{C} 15$ homologues showed weak and moderate activity, respectively (Tabbene et al. 2011). This is supposed to be due to the fact that long-chain iturins are more hydrophobic and therefore may interact more effectively with ergosterol-containing membranes of fungi and yeasts. Moreover, Malina and Shai (2005) suggested that the length of the acyl chain can also affect the specificity of lipopeptide-cell membrane interactions. They synthesized several lipopeptides with increasing acyl chain lengths of $10,12,14$, and 16 carbons to the peptides. Lipopeptides with short fatty acid chains (C10 and C12) displayed both antibacterial and antifungal activity, whereas those with long chains (C14 and C16) were active only against fungi. A possible explanation of this result is that long-chain lipopeptides more readily form oligomers and thus interact easier with the fungal membrane than with the bacterial one (Malina and Shai 2005). This might partly explain the strong antifungal and the limited antibacterial properties of iturins.

Using the fengycin-specific program, we found eight fengycins A and four fengycins B (Table 2, Fig. 2b). Fengycins A consist of the saturated $\mathrm{C} 14$ to $\mathrm{C} 18$ homologues and $\mathrm{C} 15$ to $\mathrm{C} 17$ containing a single double bond in the fatty acyl chain. Fengycins B comprise C15 to C18 homologues with a saturated acyl chain. Fengycins A are present in our sample in a larger quantity compared to fengycins $\mathrm{B}$. The $\mathrm{C} 17$ fengycin $\mathrm{A}$ is the most abundant homologue while the $\mathrm{C} 15-\mathrm{C} 17$ homologues with unsaturated acyl chain appear to be the least abundant ones. Among fengycins $\mathrm{B}, \mathrm{C} 17$ is the most abundant homologue and $\mathrm{C} 18$ is the least. Although fengycin homologues have long fatty acyl chains (up to C19), they are less hemolytic than iturins and more active toward filamentous fungi (Jacques 2011). Indeed, in our study we found that fengycins are bioactive at all tested concentrations while iturins display an inhibitory effect only at high concentrations (30 and $100 \mu \mathrm{g} / \mathrm{ml}$ ) (Fig. 3). Moreover, fengycins alone are significantly more active than the mix of the three c-LPs suggesting that fengycins are the major antifungal compound against Forl. This notion is supported by the microscopic observation of more severe growth restriction of fungal hyphae incubated with fengycins than with any of the other compounds (Fig. 4). The result with the mixture also shows that there is no (strong) synergy in the action of the various c-LPs (Fig. 4).
Table 2 c-LPs production by B. subtilis HC8 as detected by LC-MS

\begin{tabular}{lll}
\hline Cyclic lipopeptide family & Molecular mass $[\mathrm{M}-\mathrm{H}]^{+}$ & Homologue \\
\hline Iturin A & 1043.7 & $\mathrm{C}-14$ \\
& 1057.74 & $\mathrm{C}-15$ \\
& 1071.75 & $\mathrm{C}-16$ \\
& 1085.71 & $\mathrm{C}-17$ \\
Fengycin A $^{\mathrm{a}}$ & 1436.18 & $\mathrm{C}-14$ \\
& 1450.16 & $\mathrm{C}-15$ \\
& 1464.14 & $\mathrm{C}-16$ \\
& 1478.12 & $\mathrm{C}-17$ \\
& 1492.16 & $\mathrm{C}-18$ \\
& 1448.15 & $\mathrm{C}=15^{\mathrm{c}}$ \\
Fengycin B & 1462.19 & $\mathrm{C}=16^{\mathrm{c}}$ \\
& 1476.1 & $\mathrm{C}=17^{\mathrm{c}}$ \\
& 1478.05 & $\mathrm{C}-15$ \\
& 1492.16 & $\mathrm{C}-16$ \\
Surfactin $^{\mathrm{b}}$ & 1506.2 & $\mathrm{C}-17$ \\
& 1521.22 & $\mathrm{C}-18$ \\
& 994.21 & $\mathrm{C}-12$ \\
& 1008.75 & $\mathrm{C}-13$ \\
& 1022.33 & $\mathrm{C}-14$ \\
& 1036.87 & $\mathrm{C}-15$ \\
& 1050.92 & $\mathrm{C}-16$ \\
\hline & & \\
& &
\end{tabular}

c-LPs were identified by comparing both their molecular masses and their retention times with those from the literature (Ongena et al. 2005; Ongena and Jacques 2008)

a Fengycin A contains the amino acid D-alanine in the sixth position of the peptide ring

b Fengycin B contains the amino acid D-valine in the sixth position of the peptide ring

${ }^{c}$ Double bond in the acyl chain

The surfactin-specific program revealed the presence of six out of seven known surfactins with an acyl chain from $\mathrm{C} 12$ to $\mathrm{C} 16$ and the amino acid leucine at the seventh position of the peptide ring (Table 2; Fig. 2c). The most abundant homologue is $\mathrm{C} 15$ followed by $\mathrm{C} 14, \mathrm{C} 13, \mathrm{C} 12$, and C16. Numerous studies showed that $\mathrm{C} 14$ and $\mathrm{C} 15$ surfactin homologues are the most bioactive ones with respect to their antiviral activity (Kracht et al. 1999), insecticidal activity (Assie et al. 2002), triggering several plant-defense mechanisms (Jourdan et al. 2009), and foaming properties (Razafindralambo et al. 1998). Although surfactins do not show significant antifungal activity at the concentrations tested (see Figs. 3,4), they can favor establishment and spreading of biocontrol bacteria in internal host tissues. LP has been shown to be implicated in a flagella-independent surface motility (Kinsinger et al. 2003; Leclère et al. 2006) and in the formation of biofilms (Hofemeister et al. 2004) thereby globally contributing to the ability of some bacilli to 
Fig. 3 Evaluation of antifungal activity of c-LPs against Forl. The fungal spores were incubated with c-LPs at four different concentrations and with a combination of iturins, fengycins, and surfactins. The inhibition of the fungal growth was judged as the decrease in OD620 compared to the control. Bars indicate confidence intervals
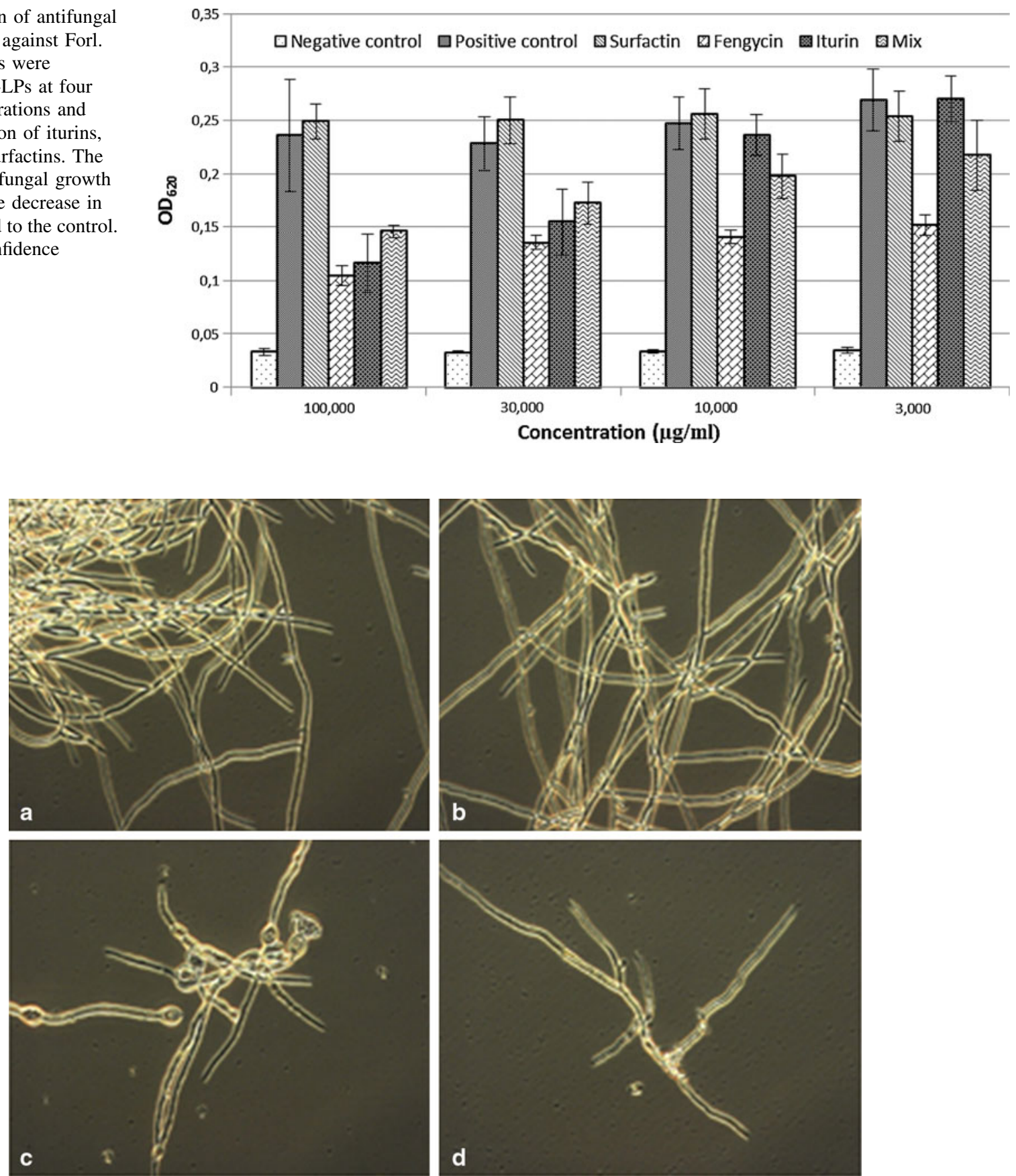

Fig. 4 Visualization of the inhibitory effect of c-LPs a methanol; b surfactins; $\mathbf{c}$ fengycins; $\mathbf{d}$ iturins. Fungal spores were treated with a $100 \mu \mathrm{g} / \mathrm{ml}$ of each c-LP and incubated at $30{ }^{\circ} \mathrm{C}$ for $25 \mathrm{~h}$

efficiently colonize surfaces of plant roots (Bais et al. 2004).

In this study, we show for the first time that an endophytic $B$. subtilis strain is able to produce all three families of c-LPs of which the fengycins displayed the strongest antifungal activity against Forl. Production of fengycins A and $\mathrm{B}$ was also reported for the endophytic bacteria B. amyloliquefaciens ES-2 (Sun et al. 2006) and B. subtilis
B-FS01 (Hu et al. 2007). However, in contrast to HC8, neither of these strains co-produces significant amounts of surfactin, fengycin, and iturin. Moreover, a very heterogeneous mixture of homologues was detected in the methanolic extract of our strain. Whether the same c-LPs and homologues are being produced during interaction of B. subtilis $\mathrm{HC} 8$ with plants and which of them are involved in its biocontrol activity remains to be established. 
Acknowledgments The research described here was supported by the Netherlands Organization for Scientific research (NWO, project number 047.018.001) and by Goskontract Minobrnauki (project number P760 from 20.05.2010) and represents part of the RussianDutch collaboration project "Center of Excellence". We thank Gerben Voshol for his help in some experiments and for critically reading the manuscript. This work also received financial support from the Program Crédit aux chercheurs $\mathrm{n}^{\circ}$ 1.5.192.08F (National Funds for Scientific Research, FRS-FNRS, Belgium). M. Ongena is Research Associate at the FRS-FNRS.

Open Access This article is distributed under the terms of the Creative Commons Attribution License which permits any use, distribution, and reproduction in any medium, provided the original author(s) and the source are credited.

\section{References}

Arguelles-Arias A, Ongena M, Halimi B, Lara Y, Brans A, Joris B, Fickers P (2009) Bacillus amyloliquefaciens GA1 as a source of potent antibiotics and other secondary metabolites for biocontrol of plant pathogens. Microb Cell Fact 8:63

Assie LK, Deleu M, Arnaud L, Paquot M, Thonart P, Gaspar Ch, Haubruge E (2002) Insecticide activity of surfactins and iturins from a biopesticide Bacillus subtilis Cohn (S499 strain). Meded Rijksuniv Gent Fak Landbouwkd Toegep Biol Wet 67:647-655

Bais HP, Park SW, Weir TL, Callaway RM, Vivanco JM (2004) How plants communicate using the underground information superhighway. Trends Plant Sci 9:26-32

Bonmatin J-M, Laprevote O, Peypoux F (2003) Diversity among microbial cyclic lipopeptides: iturins and surfactins. Activitystructure relationships to design new bioactive agents. Comb Chern High Throughput Screen 6:541-556

Grangemard I, Peypoux F, Wallach J, Das BC, Labbé H, Caille A, Genest M, Maget-Dana R, Ptak M, Bonmatin J (1997) Lipopeptides with improved properties: structure by NMR, purification by HPLC and structure-activity relationships of new isoleucyl-rich surfactins. J Pept Sci 3:145-154

Haas D, Défago G (2005) Biological control of soil-borne pathogens by fluorescent pseudomonads. Nat Rev Microbiol 3:307-319

Hofemeister J, Conrad B, Adler B, Hofemeister B, Feesche J, Kucheryava N et al (2004) Genetic analysis of the biosynthesis of non-ribosomal peptide- and polyketide-like antibiotics, iron uptake and biofilm formation by Bacillus subtilis A1/3. Mol Genet Genomics 272:363-378

Hu LB, Shi ZQ, Zhang T, Yang ZM (2007) Fengycin antibiotics isolated from B-FS01 culture inhibit the growth of Fusarium moniliforme Sheldon ATCC 38932. FEMS Microbiol Lett 272:91-98

Jacques P (2011) Surfactin and other lipopeptides from Bacillus spp. Microbiol Monogr 20:57-91

Jourdan E, Henry G, Duby F, Dommes J, Barthelemy JP, Thonart P, Ongena M (2009) Insights into the defense-related events occurring in plant cells following perception of surfactin-type lipopeptide from Bacillus subtilis. Mol Plant Microbe Interact 22:456-468

Kinsinger RF, Shirk MC, Fall R (2003) Rapid surface motility and biofilm formation in Bacillus subtilis is dependent on extracellular surfactin and potassium ion. J Bacteriol 185:5627-5631

Kracht M, Rokos H, Ozel M, Kowall M, Pauli G, Vater J (1999) Antiviral and hemolytic activities of surfactin isoforms and their methyl ester derivatives. J Antibiot 52:613-619
Leclère V, Marti R, Béchet M, Fickers P, Jacques P (2006) The lipopeptides mycosubtilin and surfactin enhance spreading of Bacillus subtilis strains by their surface-active properties. Arch Microbiol 186:475-483

Lugtenberg B, Kamilova F (2009) Plant-growth-promoting rhizobacteria. Annu Rev Microbiol 63:541-556

Maget-Dana R, Thimon L, Peypoux F, Ptak M (1992) Surfactin/iturin A interactions may explain the synergistic effect of surfactin on the biological properties of iturin A. Biochimie 74:1047-1051

Malfanova N, Kamilova F, Validov Sh, Shcherbakov A, Chebotar V, Tikhonovich I, Lugtenberg B (2011) Characterization of Bacillus subtilis HC8, a novel plant-beneficial endophytic strain from giant hogweed. Microbial Biotech 4:523-532

Malina A, Shai Y (2005) Conjugation of fatty acids with different lengths modulates the antibacterial and antifungal activity of a cationic biologically inactive peptide. Biochem J 390:695-702

Ongena M, Jacques P (2008) Bacillus lipopeptides: versatile weapons for plant disease biocontrol. Trends Microbiol 16:115-125

Ongena M, Jacques P, Touré Y, Destain J, Jabrane A, Thonart P (2005) Involvement of fengycin-type lipopeptides in the multifaceted biocontrol potential of Bacillus subtilis. Appl Microbiol Biotechnol 69:29-38

Ongena M, Adam A, Jourdan E, Paquot M, Brans A, Joris B, Arpigny JL, Thonart P (2007) Surfactin and fengycin lipopeptides of Bacillus subtilis as elicitors of induced systemic resistance in plants. Environ Microbiol 9:1084-1090

Peypoux F, Bonmatin JM, Labbe H, Grangemard I, Das BC, Tak M, Wallach J, Michel G (1994) [Ala 4] surfactin, a novel isoform from Bacillus subtilis studied by mass and NMR spectroscopies. Eur J Biochem 224:89-96

Razafindralambo H, Popineau Y, Deleu M, Hbid C, Jacques P, Thonart P, Paquot M (1998) Foaming properties of lipopeptides produced by Bacillus subtilis: effect of lipid and peptide structural attributes. J Agric Food Chem 46:911-916

Romero D, de Vicente A, Rakotoaly R, Dufour S, Veening J, Arrebola E et al (2007) The iturin and fengycin families of lipopeptides are key factors in antagonism of Bacillus subtilis toward Podosphaera fusca. Mol Plant Microbe Interact 20:430-440

Shai Y, Makovitzky A, Avrahami D (2006) Host defense peptides and lipopeptides: modes of action and potential candidates for the treatment of bacterial and fungal infections. Curr Protein Pept Sci 7:479-486

Sun L, Zhaoxin L, Bie X, Fengxia L, Yang S (2006) Isolation and characterization of a co-producer of fengycins and surfactins, endophytic Bacillus amyloliquefaciens ES-2, from Scutellaria baicalensis Georgi. World J Microbiol Biotechnol 22:1259-1266

Tabbene O, Kalai L, Slimene IB, Karkouch I, Elkahoui S, Gharbi A et al (2011) Anti-Candida effect of bacillomycin D-like lipopeptides from Bacillus subtilis B38. FEMS Microbiol Lett 316:108-114

Thomashow LS, Weller DM (1995) Current concepts in the use of introduced bacteria for biological disease control: mechanisms and antifungal metabolites. In: Stacey G, Keen NT (eds) Plantmicrobe interactions. Chapman \& Hall, New York, pp 187-235

Toure Y, Ongena M, Jacques P, Guiro A, Thonart P (2004) Role of lipopeptides produced by Bacillus subtilis GA1 in the reduction of grey mould disease caused by Botrytis cinerea on apple. J Appl Microbiol 96:1151-1160

Tran H, Ficke A, Asiimwe T, Höfte M, Raaijmakers JM (2007) Role of the cyclic lipopeptide massetolide A in biological control of Phytophthora infestans and in colonization of tomato plants by Pseudomonas fluorescens. New Phytol 175:731-774 